\title{
DOCTRINES AND RENTS IN JAPAN: A COMMENT ON PROFESSORS OSUKA AND NAKAMURA
}

\author{
J. MARK RAMSEYeR*
}

I

INTRODUCTION

Professors Akira Osuka and Mutsuo Nakamura provide two marvelously rich accounts of Japanese constitutional law. ${ }^{1}$ Professor Osuka's history of Japanese poverty law, for example, and Professor Nakamura's story of the constitutional attacks on economic regulation seem exactly the type of studies we need. Yet their accounts are also a bit troubling: Together, they suggest that scholars may be missing the questions they should most ask, while courts may be missing the answers they should most give.

\section{II}

\section{DOCTRINE}

Both in the United States and in Japan, we often publish assertions instead of analyses, and sentiments instead of scholarship. Both here and there, we know better. We do it anyway when we see no choice. So long as we retain our doctrinal approach to scholarship, however, we will seldom see any choice. The point is commonplace, but consider some examples from the material at hand.

After noting that Article 25 of the Japanese Constitution guarantees "minimum standards of wholesome and cultured living,"2 Professor Osuka describes the doctrinal controversy over it. Unfortunately, the controversy is a tad beside the point. Were lunch free, Article 25 would seem marvelous. As it is not, and as no obvious line distinguishes wholesome from unwholesome living, we ought to be asking what happens when the state guarantees various standards of living. Were we to draw on social science, we might learn what social consequences would result from maintaining various levels of economic inequality. We might learn how much of a tax would fund various minimum standards, and what dead-weight losses such a tax would impose. We might even learn what effect different levels of guaranteed income would have on various incentives. So long as we stick with doctrinal and textual analyses of

Copyright $(\mathcal{C} 1990$ by Law and Contemporary Problems

* Professor of Law, University of California, Los Angeles.

1. Nakamura, Freedom of Economic Activities and the Right to Property, Law \& Contemp. Probs., Spring 1990, at 1; Osuka, Welfare Rights, Law \& ConTemp. Probs., Spring 1990, at 13.

2. See Osuka, supra note 1 , at 15. 
"wholesome and cultured living," however, we will learn nothing. In this, as in so much of law, the important questions simply are not legal.

Professor Osuka urges courts to interpret the Constitution to preserve "the cultural aspect of work." 3 Now, more culture may indeed be better than less (though we who have sat through Wagner's Ring may wonder), but culture is no freer than lunch, and the state cannot create culture by fiat. As a result, if the state requires employers to provide workers with levels of cultural satisfaction that workers have not chosen, the result will necessarily be Kaldor-Hicks inefficient. ${ }^{4}$ For two things will follow. First, any requirement that employers supply a given level of cultural satisfaction will function much like a minimum safety standard. As such, it will generally raise the total compensation package (money plus culture) that employees who keep their jobs receive, reduce the cash compensation to those employees, and throw the rest out of work. Second, the requirement will mandate a mix of cultural satisfaction and money in the compensation package that even those employees who do stay employed could have but likely would not have chosen. Had employees wanted such satisfaction, after all, they could have bargained for it on their own.

Lost in these doctrinal analyses is the point that people make these bargains. When deciding whether to work, how hard to work, and where to work, people choose among (and thus implicitly bargain for) consumption packages that include various levels of leisure, money, security, excitementand culture. Our obsession with doctrine causes us to miss all this because doctrine misses the world: Necessarily, it misses the way people respond to courts, to constitutions, and to the way courts interpret constitutions. How people will respond if the state guarantees employees various levels of cultural and material satisfaction-this is something we can and should be studying. Unfortunately, legal doctrine will not help. Yet until we know how people do respond to courts and constitutions, we cannot hope to know how courts should interpret constitutions.

RENTS

If Professor Osuka's article shows how scholars miss some of the questions they should most ask, Professor Nakamura shows how courts sometimes miss the whole show. ${ }^{5}$ Apparently many Japanese constitutional cases involve

3. Id. at 26 .

4. A move is "Kaldor-Hicks efficient" if "those who would gain from the change could pay compensation to those who would lose" and thus make the move beneficial to all. See Graetz, Legal Transitions: The Case of Retroactivity in Income Tax Revision, 126 U. PA. L. REv. 47, 67-68 (1977). Note that, given the subsidies the state would need to pay in order to enable the state-owned firm to compete with private employers not providing the same level of cultural satisfaction, the situation would not be much better if the state provided the employment directly.

5. Nakamura, supra note 1. 
flagrantly anticompetitive, rent-seeking ploys. ${ }^{6}$ According to the cases Professor Nakamura cites, however, so long as private groups invoke the "public interest" in a suitably elaborate fashion, they will rarely find courts blocking those ploys. ${ }^{7}$

Consider some of Professor Nakamura's examples. Rules establishing minimum distances between bathhouses effectively raise profits to existing bathhouses. After all, by increasing the cost of patronizing a rival, the rules make geographic monopolization easier. True, because the state prohibits price competition in the bathhouse industry, the restrictions may not affect price. They will, however, lessen the competition in the quality of bathhouse services. Limits on the distances between retailers and pharmacies accomplish much the same thing. ${ }^{8}$

As a result, each of these regulations enables firms in an industry to extort wealth from consumers who purchase the services, and to impose on society a net loss in the form of reduced consumption. Take bathhouses again. By reducing competition, the restrictions raise the price of a bath (given the quality of the service) above competitive levels. In so doing, they (a) transfer wealth to bathhouses from those patrons who continue to bathe at the higher price (given the level of service) and (b) create a social loss when some patrons who would have bathed in a competitive bathhouse market go unwashed because they find the services too poor (given the price). Much the same analysis applies to the other industries involved. Under current doctrine, however, so long as the industry explicitly and elaborately invokes the public interest, such restrictions are generally constitutional.

That Japanese firms manipulate the state to obtain advantageous regulatory schemes should not surprise us; ${ }^{9}$ much the same thing happens in most societies. ${ }^{10}$ Nor should the willingness of Japanese courts to protect such ploys surprise us; much the same thing happens in the United States." The Japanese-American comparison is not, however, accidental: It was Roosevelt's regulatory program that the United States Supreme Court attacked before the Court finally backed down, and it was apparently with that experience in mind that, some ten years later, Truman's lawyers in Tokyo

6. Rent-seeking refers to the ways that private groups manipulate the state to obtain supracompetitive returns (to obtain monopoly "rents"). See generally TOWARD a THEORY OF THE RENTSeeking Society (J. Buchanan, R. Tollison \& G. Tullock eds. 1980); Peltzman, Toward a More General Theory of Regulation, 19 J. L. \& ECON. 211 (1976); Stigler, The Theory of Economic Regulation, 2 BELL J. ECON. \& MGMT. SCI. 3 (1971).

7. Compare 1302 Hanrei Jihō 159 (Sup. Ct., Jan. 20, 1989) (bathhouse regulation held constitutional) with K.K. Kadoyoshi v. Hiroshima Prefecture, 29 Minshū 572 (Sup. Ct., G.B., Apr. 30, 1975) (pharmacy regulation held unconstitutional for lack of sufficiently compelling public interest rationale).

8. Similarly, the restrictions on job placement agencies increase the monopsonistic power of employers by raising the cost of job searches to potential employees.

9. See F. Rosenbluth, Financial Politics in Contemporary Japan 17-49 (1989).

10. See, e.g., M. Olson, The Rise and Decline of Nations (1982); S. Popkin, The Rational Peasant: The Political Economy of Rural Society in Vietnam (1979); Toward a Political Economy of Development: A Rational Choice Perspective (R. Bates ed. 1988).

11. See generally R. Epstein, Takings: Private. Property and the Power of Eminent Domain (1985); Miller, The True Story of Carolene Products, 1987 Sup. CT. REv, 397. 
installed a constitution that dropped "property" from the rights protected by due process. ${ }^{12}$

The same analysis applies to Professor Osuka's program to let professors structure the educational services industry. Professor Osuka argues that in education "social rights and civil liberties are closely interconnected." 13 As a result, says he, the state should let suppliers in the educational services industry determine their own regulatory structure. Unfortunately, almost all modern studies of regulation suggest that industry suppliers are among the last groups who should be allowed to structure regulatory schemes. ${ }^{14}$ The Japanese state probably restricted competition among bathhouses, retailers, and pharmacies, after all, precisely because it lets bathhouses, retailers, and pharmacies dominate the regulatory process.

Accordingly, professors may be among the worst people to regulate the educational services industry. ${ }^{15}$ Plenty of casual evidence confirms the point. In the United States, for example, professors have largely wrested control over universities away from students and benefactors, and control over the industry from everyone else. They dominate accreditation committees and use accreditation standards to try to enforce anticompetitive terms within the industry. ${ }^{16}$ Under those standards, for instance, firms (universities) may not fire even flagrantly unproductive workers (see tenure rules). Neither can they hire low-cost potential competitors (see degree requirements for hiring). ${ }^{17}$

Professor Osuka argues that the educational services industry involves values that are more "fundamental" than values elsewhere, and that those values justify this departure from common economic sense. Maybe so-but we should think twice. Members of an industry almost always argue that theirs is uniquely fundamental: We learn from Professor Nakamura that even junk dealers have successfully asserted a public interest in regulation. ${ }^{18} \mathrm{We}$ need more, this ought to suggest, before we decide education is so special.

\section{IV}

\section{Conclusion}

Professors Osuka and Nakamura give us wonderfully rich accounts of Japanese constitutional law. In so doing, though, they also give us rich accounts of where scholars and courts have gone wrong. In Japan, as here in the United States, many legal scholars apparently retain their fascination with doctrine. In the process, they (a) miss the most important problems they

12. See 1947 Const. art. 31; Osuka, supra note 1, at 16

13. Osuka, supra note 1 , at 26.

14. See generally Stigler, supra note 6 .

15. See, e.g., Manne, The Political Economy of Modern Universities, in The Economics of Legal Relationships 614, 625-29 (H. Manne ed. 1975).

16. Loss of accreditation often drives professional schools out of business.

17. In some ways, the situation in Japan is quite similar. See, e.g., Hall, Organizational Paralysis: The Case of Todai, in Modern Japanese Organization and Decision-Making 304 (E. Vogel ed. 1975).

18. Japan v. Manabe, 7 Keishū 577, 580 (Sup. C.., G.B., Mar. 18, 1953) 1953); see Nakamura, supra note 1 , at 4 . 
could solve (what would happen if the state did X?) and (b) instead try to answer questions about which (not having considered problem (a)) they necessarily have less to say (what should the state do?). In Japan, as here, courts have largely renounced the power to stop private business groups from manipulating the state to obtain wealth transfers from consumers. In the process, they have let those groups impose large welfare losses on everyone else. In this respect, the state of constitutional law may not be much worse in Japan than in the United States; apparently, however, it is not much better. 
